\title{
Warning and Crisis: A Perspective of Short-term International Capital Flows*
}

\author{
Rong Qiu ${ }^{1, * *}$ Haojun $\mathrm{Li}^{1}$ \\ ${ }^{1}$ Guizhou University of Finance and Economics, Guiyang, Guizhou, China \\ ${ }^{* *}$ Corresponding author. Email: 200901005@mail.gufe.edu.cn
}

\begin{abstract}
With the further deepening of economic globalization, short-term international capital flows are becoming more and more frequent, which have different degrees of impact on the global financial market and the financial stability of various countries in the world. Since the Mexican financial crisis and the Asian financial crisis in 1997, a large number of malignant financial cases caused by short-term international capital flows have emerged in an endless stream, causing people to rethink the international capital flows. The US subprime mortgage crisis in 2008, the European debt crisis in 2010 and the Chinese stock market disaster in 2015 have once again aroused the attention of governments and scholars around the world for short-term international capital flows. Through the analysis of the European debt crisis and the 2015 stock market disaster, this paper studies the role of shortterm international capital flows, and explains it in combination with relevant economic indicators. Finally, taking the development of China's stock market as the data, it demonstrates the research conclusion: under the guidance of the optimal policy objectives, it must strictly focus on the relevant warning line, strengthen the supervision of short-term international capital flows, Maintain financial stability and security.
\end{abstract}

Keywords: Debt chain, Financial crisis, Capital regulation.

\section{INTRODUCTION}

Since the 1990s, with the further deepening of the globalization of financial market, the short-term international capital flow has become more complex and diversified. Capital not only flows from developed countries to developing countries, but also begins to export capital to other countries with the development of the global economy. It is undeniable that short-term international capital flows promote the improvement of the global market and the economic development of the capital importing countries. However, due to its speculative nature, the uncertainty of the flows and other risks, once large-scale capital flows in and out, it will bring huge fluctuations and even crises to the national and even the global economy. From the Asian financial crisis in 1997, the US subprime crisis in 2008 to the European debt crisis and the

*Project: This article is one of the research results of the new agricultural science research and reform practice project of the Ministry of Education in 2020. Project name: Research on the new agricultural talent training system based on the "four aspects". Project leader: Qiu Rong. turbulence in China's stock market in 2015, the essence lies in the fact that the large-scale inflow and outflow of short-term international capital have seriously impacted the stability of domestic financial market and financial order, while the Chinese government lacks sufficient attention and supervision on short-term international capital flow.

Due to the impact of the epidemic, the global economy is facing recovery. Therefore, it is necessary to be strictly vigilant about the flow of short-term international capital. In particular, it is necessary to be highly vigilant about maintaining economic development through borrowing to prevent the financial crisis caused by the large-scale inflow and outflow of short-term international capital caused by loan capital.

\section{QUESTION}

As one of the contents of economic globalization, the free flows of international capital has been highly concerned by the government and scholars. Especially after the 1990s, western countries have taken a series of measures to 
consolidate and expand their global dominant position, and at the same time, they have also promoted the flows of short-term international capital. The most representative is the quantitative easing policy of the United States. Under the background of economic globalization and financial marketization, the free flows of short-term international capital in the world financial market is speeding up. While improving the market and developing finance, the large-scale outflows of short-term international capital plays an accelerator role in the outbreak of financial crisis[1]. But the short-term international capital flows will inevitably lead to crisis

The outbreak of the Mexican financial crisis, the Asian financial crisis and the Russian rouble crisis makes people re-examine the impact of shortterm international capital free flows. During the outbreak of the US subprime mortgage crisis, the European debt crisis and the 2015 stock market disaster in China, there is a common feature - the reversal of the direction of large-scale short-term international capital flows. These events put the liquidity of short-term international capital in front of scholars again, and further triggered the thinking of the liquidity of short-term international capital.

At present, great changes have taken place in China's external economic environment. In the face of regional local conflicts, the global economic recovery is unbalanced. All these have further increased the uncertainty of the global economy. The risk aversion characteristics of short-term international capital have further increased. The short-term international capital free flows has become an important factor affecting financial security. Therefore, the choice of the scope of capital control and the degree of free flows has become an unavoidable topic in national governance.

\section{THE THEORY AND CONCEPT}

\subsection{The Theory}

The theory of international capital flows comes from the theory of international trade. With the continuous development of the world economy, the theory of international capital flows is constantly enriched and improved.

The motivation theory of international capital flows includes single motivation theory and complex motivation theory. Besides interest rate, there are many factors that cause international capital flows, such as risk aversion, investment preference and so on; Markowitz's portfolio theory holds that the return of capital market affects the short-term international capital flows to a certain extent; According to Fisher's theory of international capital flows, the difference of interest rate is the basic reason of international capital flows. In the study of the increasingly complex and frequent global international capital flows, the most influential theory is Mundell's "Impossible Triangle" theory. The theory shows that to maintain the complete free flows of capital and to implement flexible monetary policy will inevitably lead to the instability of market currency and the corresponding financial risks[2]. This theory provides a general direction for the choice of policy objectives in the macro financial management of various countries.

\subsection{The Concept}

International capital flows is mainly manifested in three forms: direct investment, international securities investment and other investment. It can be divided into long-term international capital and short-term international capital by one year. The short-term international capital flows generally refers to the speculative capital that the international capital with a service life of less than one year frequently moves among countries in the world for the purpose of earning high profits. The typical characteristics are strong profit seeking and liquidity.

\subsection{The Index of Financial Crisis}

In addition to the existing measurement indicators including debt ratio, debt ratio and so on, the five financial measurement indicators in "Table $1 "$ are mainly used to analyze whether a country's financial market is at risk due to short-term international capital flows.

Table 1. Warning line standard of short-term international capital flows data

\begin{tabular}{|l|l|}
\hline \multicolumn{1}{|c|}{ Index } & Percentage (\%) \\
\hline $\begin{array}{l}\text { (1) short-term debt / foreign } \\
\text { exchange reserves }\end{array}$ & $70-100$ \\
\hline (2)Foreign debt / GDP & 30 \\
\hline (3)Current account deficit / GDP[3] & 5 \\
\hline $\begin{array}{l}\text { (4)(FDI + current account deficit) / } \\
\text { GDP }\end{array}$ & $-2.5--5$ \\
\hline $\begin{array}{l}\text { (5) short-term foreign debt / total } \\
\text { foreign debt }\end{array}$ & 25 \\
\hline
\end{tabular}

Data from the wind database, the international financial statistics database and the World Bank official website. 
This paper uses the above indicators to analyze the short-term international capital flows in the financial market, that is, the quantity ratio of foreign capital to domestic capital $(\mathrm{K})$, to monitor the capital flows in the financial market, so as to prevent financial risks and avoid financial turbulence, Safeguard financial security.

This financial indicator is described as follows: $\mathrm{K}=\mathrm{FC} / \mathrm{DC}$

FC is the amount of foreign capital in a country's financial market in a certain period, DC is the amount of domestic capital in a country's financial market in a certain period.

\section{CASE STUDY}

\subsection{Case One: European Debt Crisis}

In early October 2009, the Greek government suddenly announced that the proportion of government public debt and fiscal deficit to GDP in that year is expected to reach $113 \%$ and $12.7 \%$ respectively, far exceeding the limit of $60 \%$ and $3 \%$ stipulated by the European Union, which opened the prelude to the Greek debt crisis.

There are several reasons for the debt crisis:

First, the loss of monetary sovereignty. On January 1, 2001, Greece joined the euro area and began to use the euro. As the most independent central bank, the European Central Bank is not under the command of EU member governments and is prohibited from providing loans to them.
When the Greek government has a budget deficit, it can not exchange funds from the European Central Bank through selling countries, but can only obtain funds by borrowing from international financial institutions. When the Greek government borrows a large amount of foreign debt with the guarantee of sovereignty, and the national economic strength is not enough to repay the foreign debt, the sovereign debt crisis is inevitable.

Second, international speculative capital is boosting the situation. The Greek government turned to Goldman Sachs to design a "currency swap" for it, covering up a 1 billion euro debt, and Goldman got a 300 million euro Commission. At the same time, due to Greece's continuous high debt economy operation mode, Goldman Sachs purchased a 20-year CDS with a term of 1 billion euro in order to reduce investment risk. With the expiration of the contract at that time, Greece's debt problems appeared, and the value of CDS underwriting Greece's ability to pay doubled. Goldman Sachs and other international investment institutions made a large-scale short of Greece's CDS and benefited from it again.

Third, a heavy debt burden. Before joining the euro area, Greece maintained its economic operation through a high debt ratio. After joining the euro area in 2001, Greece's debt ratio continued to rise. From 1997 to 2010, the debt ratio of the Greek government was more than $100 \%$, and in 2010 , it was more than $140 \%$. This kind of debt economic operation mode is feasible in the shortterm, but it lacks durability.

Table 2. Data indicators of short-term international capital flows in Greece from 2008 to 2014

\begin{tabular}{|l|l|l|l|l|l|l|l|}
\hline \multicolumn{1}{|c|}{ Index } & \multicolumn{1}{|c|}{2008} & \multicolumn{1}{|c|}{2009} & \multicolumn{1}{|c|}{2010} & \multicolumn{1}{|c|}{2011} & 2012 & \multicolumn{1}{|c|}{2013} & \multicolumn{1}{|c|}{2014} \\
\hline (1)Current account deficit/ GDP(\%) & -6.15 & -4.72 & -4.47 & -4.78 & 1.26 & 0.33 & 0.51 \\
\hline Deviation from warning line & -11.15 & -9.72 & -9.47 & -9.78 & -3.74 & -4.67 & -4.49 \\
\hline (2)short-term debt / total debt(\%) & 2.40 & 3.86 & 3.06 & 3.51 & 5.54 & 3.81 & 4.96 \\
\hline Deviation from warning line & -22.6 & -21.14 & -21.94 & -21.49 & -19.46 & -21.19 & -20.04 \\
\hline $\begin{array}{l}\text { (3)short-term debt / foreign exchange } \\
\text { reserves(\%) }\end{array}$ & 2675 & 1083 & 1121 & 1451 & 1926 & 1243 & 1215 \\
\hline Deviation from warning line & 2575 & 983 & 1021 & 1351 & 1826 & 1143 & 1115 \\
\hline $\begin{array}{l}\text { (4)(FDI + current account deficit) / } \\
\text { GDP(\%) }\end{array}$ & -16.57 & -18.39 & 0.68 & 30.31 & -50.20 & -19.86 & 18.46 \\
\hline Deviation from warning line & -14.32 & -15.89 & 3.18 & 32.81 & -47.7 & -17.36 & 20.96 \\
\hline
\end{tabular}

Data from The Greek_economy_24_12_2015

It can be seen from the "Table 2" that from 2008 to 2014 , the ratio of total Greek debt to GDP and short-term foreign debt to foreign exchange reserves has far exceeded the international warning line of $30 \%$ and $100 \%$, and the ratio of Greek debt to GDP has even reached $175 \%$. The debt problem is serious. In 2009 , Greece's debt ratio was $124.9 \%$, far exceeding the warning line of $30 \%$. In 2009, the ratio of Greek government's total debt to GDP was $126.7 \%$. On October 20, 2009, Greece's fiscal deficit accounted for $127 \%$ of GDP, debt ratio was $113 \%$, debt/GDP reached $113.4 \%$, far exceeding the warning line of $100 \%$. From 2012 to 2014, the proportion of Greek government's total debt to GDP 
has been maintained at more than $140 \%$, and the highest proportion of Greek government's total debt to GDP reached $171 \%$ in 2014, further aggravating the Greek debt problem. In July 2015, Greece's debt crisis deepened and successfully triggered a decade long debt crisis that swept the entire euro area.

According to the "Impossible Triangle" theory, the Greek government should implement a fixed exchange rate system while giving up currency sovereignty and allowing capital to flows freely. However, its exchange rate is directly controlled by the European Central Bank, which implements fixed exchange rate internally and floating exchange rate externally. Therefore, the free flows of international capital will inevitably impact the fixed exchange rate, which not only meets the needs of Greek government expenditure, but also promotes the growth trend of debt scale, making the debt problem more serious. As a result, the unlimited accumulation of old and new debt completely dragged Greece into the debt quagmire, and finally a crisis broke out.

\subsection{Case Two: China's Stock Market Turbulence}

From the second half of 2014, the market of Ashare stock market was very good. On June 12, 2015, the Shanghai Composite Index reached 5178 points. However, from the 15 th, the stock market fell sharply. On August 26, the stock index fell to

Table 3. Financing situation of China's A-share stock market from 2008 to 2015 (unit: 100 million yuan)

\begin{tabular}{|l|l|l|l|l|}
\hline Time & $\begin{array}{c}\text { Amount of } \\
\text { domestic } \\
\text { securities } \\
\text { financing }\end{array}$ & $\begin{array}{c}\text { Financing amount } \\
\text { of overseas } \\
\text { securities }\end{array}$ & $\begin{array}{c}\text { Overseas financing amount } \\
\text { / domestic financing } \\
\text { amount } \% \text { \% }\end{array}$ & $\begin{array}{c}\text { Deviation from warning } \\
\text { line }(15 \%-20 \%)\end{array}$ \\
\hline 2008 & 3596.16 & 317.27 & 8.82 & -6.18 \\
\hline 2009 & 4609.54 & 1073.18 & 23.28 & 8.28 \\
\hline 2010 & 10275.20 & 2365.62 & 23.02 & 8.02 \\
\hline 2011 & 6780.47 & 725.75 & 10.70 & -4.3 \\
\hline 2012 & 1359.55 & 419.97 & 30.89 & 15.89 \\
\hline 2013 & 6884.83 & 1063.89 & 15.45 & 0.45 \\
\hline 2014 & 8412.40 & 2217.78 & 26.36 & 26.36 \\
\hline 2015 & 29493.63 & -801.05 & -2.72 & -17.72 \\
\hline
\end{tabular}

Data from CSRC website

It can be seen from the "Table 3" that in 2009, 2010 and 2014, the proportion of overseas and domestic financing exceeded $23 \%$, far exceeding the warning line of $15 \%$, and a large number of short-term arbitrage capital flooded the stock market. Since the end of June 2015, China's stock market began to fall sharply, and the amount of overseas financing decreased rapidly, which
2927 points, causing heavy losses. The stock market turmoil has had a huge impact on China's financial market.

The root of the turbulence lies in the large inflows and outflows of short-term arbitrage capital. Before the turmoil, the excessive interpretation of policies on Internet plus, nationwide entrepreneurship and innovation of millions of people led to a large influx of hot money and the influx of securities financing and OTC capital allocation. The amount of financing issued by brokers was about 2 trillion and 400 billion, and the OTC distribution was about 4 trillion.

On the other hand, the leverage of financing is an important reason for the stock market disaster. According to the source of financing, it can be further divided into on-site financing and off-site financing. Floor financing is mainly represented by margin trading. Since March 2010, the balance of the two financing has steadily increased from 7 million yuan to more than 2 trillion yuan in 2015 , with a peak of 2.27 trillion yuan. In addition, OTC allocation is an important source of leverage funds. Due to regulatory reasons, there is a lack of accurate statistics on the scale of OTC allocation. Rough statistics show that the overall scale of OTC allocation in 2015 was $1.5-1.8$ trillion yuan. During this period, the stock market soared, and the leverage of capital was very significant. directly decreased from $16.36 \%$ in 2014 to $-2.72 \%$. But the tightening monetary policy adopted by the monetary authorities caused the interest rate reversal, a large number of short-term arbitrage capital fled quickly, strengthened the downward trend of the stock market, exacerbated the stock market turbulence. 
Table 4. Data of China's short-term international capital flows from 2008 to 2015

\begin{tabular}{|c|c|c|c|c|c|c|c|c|}
\hline Time & 2008 & 2009 & 2010 & 2011 & 2012 & 2013 & 2014 & 2015 \\
\hline $\begin{array}{l}\text { (1) short-term debt / foreign } \\
\text { exchange reserves }(\%)\end{array}$ & 11.6 & 10.8 & 13.2 & 15.7 & 16.3 & 17.7 & 33.8 & 26.6 \\
\hline Deviation from warning line & -58.4 & -59.2 & -56.8 & -54.3 & -53.7 & -52.3 & -36.2 & -43.4 \\
\hline (2)Foreign debt / GDP(\%) & 8.50 & 8.40 & 9.01 & 9.21 & 8.64 & 9.02 & 16.98 & 12.50 \\
\hline Deviation from warning line & -21.5 & -21.6 & -20.99 & -20.79 & -21.36 & -20.98 & -13.02 & -17.5 \\
\hline (3)Current account deficit / GDP(\%) & 0.39 & 3.26 & 2.62 & 2.78 & 1.65 & 1.47 & 2.13 & 4.13 \\
\hline Deviation from warning line & -4.61 & -1.74 & -2.38 & -2.22 & -3.35 & -3.53 & -2.87 & -0.87 \\
\hline $\begin{array}{l}\text { (4)(FDI + current account deficit) / } \\
\text { GDP(\%) }\end{array}$ & 2.41 & 5.02 & 4.36 & 2.86 & 2.96 & 2.70 & 3.27 & 5.28 \\
\hline Deviation from warning line & -2.59 & 0.02 & -0.64 & -2.14 & -2.04 & -2.3 & -1.73 & 0.28 \\
\hline $\begin{array}{l}\text { (5) short-term foreign debt / total } \\
\text { foreign } \operatorname{debt}(\%)\end{array}$ & 58.0 & 60.5 & 68.4 & 72.1 & 73.4 & 78.4 & 72.9 & 64.2 \\
\hline Deviation from warning line & 33 & 35.5 & 43.4 & 47.1 & 48.4 & 53.4 & 47.9 & 39.2 \\
\hline
\end{tabular}

a Data from China Bureau of statistics and administration of foreign exchange.

From 2008 to 2015 ("Table 4"), China's foreign debt increased gradually, especially the short-term foreign debt. Affected by the financial crisis in 2008, foreign exchange reserves decreased to US $\$ 3$ trillion, but short-term debt/foreign exchange reserves continued to rise. Among the above five indicators, the total amount of short-term debt/foreign debt exceeds the warning line of $25 \%$, and the warning line of (FDI + current account deficit)/GDP exceeds 5\% in 2009 and 2015, which indicates that there is too much foreign capital inflows, and most of the foreign capital flows into the stock market in the form of stocks and securities, which increases the supervision difficulty of capital flows, and to some extent leads to the deterioration of the subsequent stock market disaster.

Strictly speaking, China is not strictly in accordance with the "Impossible Triangle" theory to formulate various policies to ensure the stability of exchange rate and the independence of monetary policy, and slightly relax the restrictions on the free flows of capital on the premise of the capital account is not open. It is the deregulation of capital that leads to the influx of a large number of hot money, especially the increasing amount of overseas financing, which leads to the false prosperity of the stock market and the subsequent stock disaster.

\subsection{Case Three: Data Analysis of China's Current Short-term International Capital Flows}

With the further deepening of economic globalization and the further opening of China's financial market, good economic development trend and potential have attracted a large number of short-term international capital. According to statistics, in 2018, foreign direct investment in China amounted to US $\$ 139$ billion, with a total position of US $\$ 1965.2$ billion, short-term foreign debt of US $\$ 1219$ billion, long-term foreign debt of US $\$ 533.9$ billion, and total liabilities of US $\$ 1752.9$ billion.

Table 5. Data of China's short-term international capital flows from 2018 to 2020

\begin{tabular}{|c|c|c|c|}
\hline Time & 2017 & 2018 & 2019 \\
\hline (1) short-term debt / foreign exchange reserves(\%) & 36.5 & 42.0 & 39.2 \\
\hline Deviation from warning line & -335 & -28 & -30.8 \\
\hline (2)Foreign debt / GDP(\%) & 13.51 & 14 & 14.41 \\
\hline Deviation from warning line & -16.49 & -16 & -15.59 \\
\hline (3)Current account deficit / GDP(\%) & 1.46 & 0.68 & 1.43 \\
\hline Deviation from warning line & -3.54 & -4.32 & -3.57 \\
\hline (4)(FDI + current account deficit) / GDP(\%) & 2.53 & 1.64 & 2.39 \\
\hline Deviation from warning line & -2.47 & -3.36 & -2.61 \\
\hline (5)short-term foreign debt / total foreign debt(\%) & 65.1 & 62.0 & 58.9 \\
\hline Deviation from warning line & 40.1 & 37 & 33.9 \\
\hline
\end{tabular}


It can be seen from the "Table 5" that the above indicators in China are in the safe range. China's debt ratio has been as high as $70 \%$ for three consecutive years, which shows that China's foreign debt has been increasing, especially the proportion of short-term debt is too high. From 2017 to 2019, China's debt ratio will remain at about $14.3 \%$, and the debt ratio will rise from $72.60 \%$ to $77.80 \%$, indicating that China is heavily dependent on foreign investment at the present stage. Once the global financial market is in chaos, it is bound to endanger China's financial security. At the same time, the higher foreign exchange reserves are facing the situation of devaluation and shrinkage due to the Western quantitative easing policy, which restricts the government's solvency and crisis handling ability to a certain extent.

Affected by many internal and external factors, China's economic growth has slowed down. The GDP growth rate in 2018 is $6.6 \%$, which is $0.3 \%$ lower than that in 2017. While borrowing, the scale of short-term debt and the scale and speed of foreign capital introduction should be controlled strictly, so as to prevent the debt crisis caused by the debt growth rate exceeding the GDP growth rate and the depreciation rate of foreign exchange reserves.

\section{SUGGESTIONS}

Through the analysis of the European debt crisis and China's stock market turmoil in 2015, it is found that without controlling the short-term international capital inflows and outflows strictly, it is bound to endanger financial security and even lead to economic crisis. Therefore, measures must be taken to prevent and resolve the major financial risks brought by short-term international capital flows and the resulting financial crisis.

\subsection{Maintaining Good Macroeconomic Fundamentals}

At this stage, it is necessary to accelerate the construction of "double cycle" development pattern. First, expand domestic demand, focus on improving the domestic circulation system, build a unified domestic market, and give full play to China's huge consumer market advantage; Secondly, improve the quality of opening up, optimize the environment of opening up, and promote the positive interaction of domestic and international double cycle; Finally, it must take measures to encourage scientific and technological innovation, build a modern industrial system, and give new impetus to economic development. In order to get rid of the inertia of the traditional growth model, reduce the dependence on foreign markets and foreign capital, maintain good macroeconomic fundamentals, and avoid the financial turmoil caused by the large inflows and outflows of short-term international capital to the maximum extent.

\subsection{Maintaining the Adequacy and Value Preservation of Foreign Exchange Reserves}

That is to say, the total amount should be sufficient, the structure should be reasonable and the value of assets should be maintained. On the premise of sufficient foreign exchange reserves, The reserve assets shall be reasonably structured and maintained. Therefore, it is necessary to make accurate statistics of various economic indicators, predict the future economic development trend, and adjust the scale of foreign exchange reserves to adapt to the level of China's economic development. In terms of structure, the currency and proportion of reserve assets should be reasonably determined to promote people's internationalization process and ensure the value preservation and appreciation of reserve assets.

\subsection{Improving the Supervision of Short- term International Capital Flows}

In the context of increasingly complex shortterm international capital flows, by referring to the regulatory practices of developed countries, the early-warning system of risk index should be improved.Establish and improve external debt and capital under the framework of macro-prudential management.[4] Each and every short-term international capital flow is recorded and monitored continuously with big data on the size, direction and structure of short-term international capital,.feedback of abnormal capital flows in time, indirect maintenance of financial security[5]. Charge a fee for short-term international capital flows in proportion to increase the cost of frequent international capital flows and reduce speculative trading activities. Properly control the capital account opening process to prevent excessive fluctuations in the financial market.[6]

\subsection{Maintaining Debt Scale Reasonable}

In the face of the increasing proportion of shortterm debt in China's debt scale, measures should be 
taken to reduce the debt scale and control it in a reasonable range. First, appropriately increase taxes, such as real estate taxes and platform taxes, to increase taxes and increase national revenue. Second, encourage enterprises to use VE (Value Engineering) for innovation, maximize the innovation ability of employees, reduce production and operation costs, improve profitability and reduce lending behavior.

\section{CONCLUSION}

With the deepening of regional cooperation and the need for global economic recovery, short-term international capital flows will become more frequent and more important. However, the problems caused by them will also become more complex and diverse. To prevent a sovereign debt crisis from happening again,prevent the adverse impact of short-term capital flows on the capital market[7] and improve the level of government regulation, must always be wary of short-term international capital flows to the heart, closely monitoring the speed of short-term international capital flows, size and cross-border funding trends[8], especially focus on short-term capital abnormal flow, prevent dissolve the major financial risks, avoid because of its liquidity risk and cause financial crisis.

\section{AUTHORS' CONTRIBUTIONS}

In this paper, Rong Qiu is in charge of the theoretical framework and Haojun Li is in charge of the empirical analysis.

\section{REFERENCES}

[1] Marx: Capital (Volume 2), people's publishing house, 2004.

[2] Robert A. Mundell. The theory of optimal currency areas. 1991.

[3] Liu Jiantao. Construction and analysis of early warning indicators of financial crisis [D]. Shandong University, 2010.

[4] Jing Linde. Accelerating the construction of macro Prudential Management System for cross border capital flows in China [J]. Modern management science, 2018 (04):45-47.

[5] Ma Cao. The impact of international capital flows on China's financial security [J]. Knowledge economy, 2018 (18):47 + 57.
[6] Cui yuanmiao, Wang Li, Ma Dan. Research on the impact of short-term international capital flows on stock price $[\mathrm{J}]$. Zhejiang finance, $2019(02): 35-43+20$.

[7] Wang Manyi, Lu Wei. The impact of shortterm international capital flows on China's capital market $[\mathrm{J}]$. International economic cooperation, 2018 (08): 88-91.

[8] Wu Jiawei, GE Zhizhuang. International short-term capital flows in and out of China's stock market: behavior characteristics, driving factors and impact analysis [J]. Shanghai finance, 2020 (09):2-13. 